\title{
Koalicja Wschowskich Kolędników. Między dziedzictwem kulturowym a tradycją wynalezioną
}

\author{
Koalicja Wschowskich \\ Kolędników. Between Cultural \\ Heritage and Invented Tradition
}

\begin{abstract}
Jakby ich moc mogła zmienić żywot człowieka. Jakby ludzie akceptujący tę tradycję świętowania umówili się, że w okresie świątecznego bałaganu każdy przybysz dziwacznie przebrany jest posłańcem z zaświatów, zwiastunem nowin o rychłym już może początku świata.
\end{abstract}

Anna Zadrożyńska ${ }^{x}$

Koalicja Wschowskich Kolędników to grupa młodzieży i młodych dorosłych w wieku między 20. a 30. rokiem życia, która w ciągu ostatnich kilkunastu lat wiele razy przechodziła ulicami Wschowy i dwóch przylegających do niej wsi - Przyczyny Górnej i Przyczyny Dolnej - podczas Świąt Bożego Narodzenia. Kolędnicy chodzą od domu do domu, życząc pomyślności w nadchodzącym Nowym Roku, a tam, gdzie zostaną przyjęci, dają dodatkowy występ. Mieszkańcy wsi i miasta, którzy goszczą w swych progach rozśpiewanych, roztańczonych i rozegranych przebierańców, na długo zapamiętują ich wizytę i niemal zawsze wyrażają nadzieję na to, by zobaczyć się ponownie następnego roku.

Kolęda to termin wieloznaczny², który odnosi się do wielu praktyk. Barbara Ogrodowska wymienia, że kolędą określa się w Polsce: pieśni noworoczne, dary świąteczne i datki, wizyty duszpasterzy w okresie od Nowego Roku do Wielkiego Postu oraz domowe i kościelne pieśni o Bożym

I A. Zadrożyńska, Światy, zaświaty. O tradycji świętowań w Polsce, Warszawa 2000, s. 63-64.

2 Taż, Świętowania polskie. Przewodnik po tradycji, Warszawa 2002, s. 69. 
Narodzeniu³. Według A. Zadrożyńskiej, „jeżeli weźmie się pod uwagę, że każde wędrowanie w okresie Bożego Narodzenia pod pretekstem składania życzeń i otrzymywania podarunków było właśnie kolędowaniem, to aż do wiosny można było obserwować prawie codzienne wymienianie darów słownych na dobra natury" ${ }^{4}$. Według Andrzeja Brencza, kolędowanie rozumiane jako wiejskie wędrowne widowisko teatralne to zwyczaj znany niemal w całej Europie, praktykowany na różne sposoby i w różnych terminach. Etnograf przyjmuje za Petru Caramanem, że kolęda to obrzęd uniwersalny, którego nie można przypisać jednemu narodowi mogącemu dać mu początek ${ }^{5}$. Choć B. Ogrodowska uważa, że „, chodzenie po kolędzie znane było i występowało powszechnie we wszystkich regionach i to zarówno na wsi, jak i w miastach"', to w etnograficznych dokumentacjach zwyczaju kolędowania, których analizą zajmę się w dalszej części artykułu, nie ma żadnych informacji na temat grup kolędniczych w okolicach Wschowy. Terytorium to nie cieszyło się takim zainteresowaniem badawczym pod względem obrzędowości dorocznej jak np. Rzeszowszczyzna $^{7}$. Według A. Brencza, na południu oraz zachodzie Wielkopolski, gdzie omawiany przeze mnie teren się znajduje, zwyczaj kolędowania po prostu nie występował: „Orszaki Herodów znane są na terenie prawie całej Wielkopolski, nie występują tylko w części zachodniej i południowej, gdzie brak tradycji kolędniczych"». W rozmowach przeprowadzonych przeze mnie z kolędnikami, a także podczas własnych obserwacji, jako kolędnik z dwuletnim stażem, spotkałam się jednak z twierdzeniem, że działalność Koalicji to podtrzymywanie zanikającej tradycji kolędowania. Wielu gospodarzy przyjmujących kolędników wyrażało zachwyt kultywowaniem przez nich owego zwyczaju.

Czym zatem jest kolędowanie we Wschowie? Reliktem niematerialnego dziedzictwa kulturowego, przejawem folkloryzmu czy nową, wynalezioną tradycją? Czyją jest tradycją - lokalną, czyli wschowską, czy ogólnopolską? Celem niniejszego artykułu jest próba odpowiedzi na te pytania. Aby tego dokonać, spróbuję odnaleźć genezę współczesnego kolędowania we

3 B. Ogrodowska, Zwyczaje, obrzędy, tradycje w Polsce. Maty stownik, Warszawa 200o, s. 83-85. Zob. taż, Święta polskie. Tradycja i obyczaj, Warszawa 2000, s. 67-89; taż, Radość wszelkiego stworzenia. Rzecz o adwencie i Bożym Narodzeniu - bistoria, tradycja, obyczaj polski, Warszawa 2008.

4 A. Zadrożyńska, Powtarzać czas początku, Warszawa 1985, s. 67.

5 A. Brencz, Wielkopolski rok obrzędowy. Tradycja i zmiana, Poznań 2006, s. 79.

6 B. Ogrodowska, Święta polskie..., s. 67.

7 W. Dragan, B. Maksymiuk-Pacek, Tradycyjne formy kolędowania na Rzeszowszczyźnie, [w:] Kolędowanie na Rzeszowszczyźnie, red. J. Dragan, K. Smyk, Kolbuszowa 2019, s. 55.

8 Tamże, s. 83. 
Wschowie. Opierać się będę głównie na przeprowadzonych przeze mnie rozmowach z kolędnikami, obserwacji poprzez dwukrotne uczestnictwo w kolędzie oraz analizie wybranej literatury etnograficznej dotyczącej tradycji kolędniczych. Czy Koalicja Wschowskich Kolędników nawiązuje do dawnych zwyczajów kolędniczych miasta i okolicznych wsi, stanowi rekonstrukcję przerwanego przekazu kulturowego, czy jest grupą kolędniczą wykreowaną współcześnie, powstałą z inspiracji tradycjami kolędniczymi z różnych stron Polski? Głównym problemem badawczym artykułu jest próba odpowiedzi na pytanie, w jakim stopniu wschowskie kolędowanie stanowi przejaw niematerialnego dziedzictwa, a w jakim stosunkowo niedawno wynaleziony i spopularyzowany element lokalnego krajobrazu kulturowego.

Artykuł składa się z trzech części. Pierwszą stanowi etnograficzny opis kolędowania, prezentacja grupy od momentu jej założenia do Świąt Bożego Narodzenia w 2019 r. oraz przedstawienie społecznego odbioru grupy wraz z zaangażowaniem w jej działalność lokalnych mediów i instytucji kultury. Druga część to prezentacja wschowskiego kolędowania na tle wielkopolsko-lubuskich tradycji kolędniczych w oparciu o literaturę przedmiotu. W części trzeciej zebrany materiał rozpatrywany jest w kategoriach tradycji, folkloryzmu, tradycji wynalezionej i niematerialnego dziedzictwa kulturowego.

\section{Czym jest Koalicja?}

Działalność Koalicji Wschowskich Kolędników obejmuje Wschowę - średniej wielkości miejscowość w południowo-wschodniej części województwa lubuskiego - oraz dwie sąsiadujące z nią wsie: Przyczynę Górną oraz Przyczynę Dolną. Pierwsze kolędowanie grupy miało miejsce w 2007 r. Kilkoro członków Hufca Związku Harcerstwa Polskiego Wschowa zdecydowało się zebrać w ten sposób środki na uzupełnienie wyposażenia drużyny. Przez cztery lata pieniądze zebrane podczas świąt młodzież dzieliła między siebie - harcerze mogli dokonać zakupu podstawowego sprzętu harcerskiego, którego brakowało w drużynie. Tak rzecz miała się do 20 I r., kiedy zasady kolędowania uległy zmianie. Grupa rozpoczęla wtedy bowiem współpracę z zaufaną osobą z miejscowego Ośrodka Pomocy Społecznej. Od tej pory pieniądze, które udaje się zebrać podczas świąt, przekazywane są osobom potrzebującym; działalność grupy nabrała charakteru charytatywnego. W tym czasie członkowie grupy nie nazywali jeszcze siebie Koalicją - jako taka powstała dopiero w $2013 \mathrm{r}$. z inicjatywy kilkorga najbardziej aktywnych kolędników. Chcieli oni w ten sposób poczynić pierwszy krok w stronę utworzenia oficjalnego stowarzyszenia zrzeszającego osoby pragnące brać 
udział w corocznym kolędowaniu. Zdaniem pierwszych jego członków, na terenie powiatu co jakiś czas organizowały się małe grupki kolędnicze, głównie wśród dzieci, które nazwali „straszącymi po mieście niedobitkami”. Byli zdania, że kolęda musi być rzetelnie zorganizowana - od liczby uczestników, przez repertuar i instrumenty, po starannie przygotowane stroje. We współpracy z kilkoma wschowskimi parafiami młodzież miała zamiar zorganizować szkolenia, podczas których dzieci uczyłyby się określonych kolęd i przygotowywały swoje stroje. Pomysł ten został jednak niezrealizowany do dnia dzisiejszego, a jedyną grupą posiadającą monopol na prawdziwe kolędowanie - w rozumieniu jej członków - jest właśnie Koalicja Wschowskich Kolędników.

Grupa kolędników spotyka się w Wigilię Bożego Narodzenia w ustalonym miejscu, którym z reguły jest dom jednego z jej członków. Od kilku lat w przygotowywaniu kolędy pomagają media społecznościowe. Główny organizator, a także pomysłodawca Koalicji, nazywany przez resztę członków „prezesem”, jakiś czas przed świętami tworzy wydarzenie na portalu Facebook, do którego dołączyć mogą osoby zainteresowane uczestnictwem w nadchodzącej kolędzie - pozwala to zatoczyć akcji dużo szersze kręgi, przez co zdarza się, że niektórzy kolędnicy dojeżdżają z odleglejszych miejscowości, m.in. Leszna i Sławy. Wydarzenie służy też do rozdysponowania kolędniczych postaci pośród chętnych - z odpowiednim wyprzedzeniem zamieszczana jest w nim ankieta, w której kolędnicy zaznaczają, kogo będą odgrywać. Pozwala to uniknąć powtarzających się maszkar lub braku jednej z nich. Podczas próby w Wigilię uczestnicy sprawdzają stan osobowy, przygotowują stroje i ustalają repertuar.

Akcja widowiska ma miejsce zwykle 25 i 26 grudnia - rozpoczyna się w godzinach popołudniowych, kończy natomiast około północy. Niektórzy przychodzą na miejsce zbiórki już przebrani, inni zakładają swoje stroje tuż przed wyjściem w drogę. Zdarza się, że chętnych jest na tyle dużo, że kolędnicy mogą podzielić się na dwie grupy i dotrzeć do większej ilości mieszkańców. Trasa kolędowania ustalana jest na bieżąco, jednak na mapie Wschowy i okolic jest kilka miejsc, które odwiedzane są przez Koalicję niezmiennie od lat. Są to między innymi miejsca zamieszkania kolędników lub znanych im osób, które zawsze ich przyjmują. W niektórych miejscach uczestnicy pochodu robią krótką przerwę, mają okazję odetchnąć, ogrzać się, poprawić stroje i makijaż oraz coś zjeść. Najczęściej trasa przemierzana przez kolędników rozpoczyna się w miejscu zbiórki - od kilku lat jest to ul. Moniuszki, następnie prowadzi przez miasto do jednej z najbliższych wsi, Przyczyny Dolnej lub Górnej, po czym zawraca w stronę centrum Wschowy. Kolędnicy dokonują wyboru, w której wsi będą chodzić w dany 
dzień świąt, wyznaczając w ten sposób swoją trasę. Jeden z kolędników, należący do grupy od początku jej istnienia, mówi:

Trasa kiedyś się, powiedzmy, ustaliła. Próbowaliśmy chodzić po blokach, ale słabo się to sprawdzało, bo albo nie otwierali, albo było nas za dużo, żeby się zmieścić. Zaczęliśmy więc chodzić po dzielnicach, gdzie są domki jednorodzinne. W zasadzie w większości podobny rejon i już ludzie na nas czekają co roku, ale zawsze zachęcamy młodych ludzi, żeby poszli w nasze ślady i chodzili, gdzie się da'.

Choć kolędnicy starają się występować każdego roku, zdarzają się święta, podczas których tego nie robią. Przyczyny odwołania wydarzenia są różne - w latach 2016 i 2019 kolędowanie nie odbyło się ze względu na niekorzystne warunki pogodowe. Silny deszcz może narazić uczestników na zachorowanie lub zniszczyć ich instrumenty - dętym blaszanym (np. trąbce, puzonowi) nie wyrządziłby większej szkody, czego nie można powiedzieć o drewnianych lub dętych drewnianych (np. lira korbowa, klarnet). Inną przyczyną może być brak głównego organizatora. „Prezes” na co dzień mieszka i pracuje w Poznaniu, dokąd zdarza się, że musi wyjechać jeszcze w trakcie świąt. Zdarzały się sytuacje, gdy z powodu wyjazdu „prezesa” w drugi dzień świąt reszta kolędników zrezygnowała z wyjścia. Jest to świadectwo swego rodzaju centralizacji odpowiedzialności za działalność grupy i - przyjmując, tak jak robią to mieszkańcy Wschowy, że kolędowanie jest ich lokalną tradycją - odpowiedzialności za podtrzymywanie zwyczaju. Kolejnym czynnikiem, który wpływa na częstotliwość zjawiska, jest obecność i ilość instrumentów. W 2019 r. zbiegiem okoliczności żaden z grających członków grupy nie mógł wziąć udziału w kolędzie. Początkowo członkowie Koalicji zastanawiali się, czy jest sens kolędować bez instrumentów, ostatecznie jednak akcję odwołano ze względu na silny deszcz.

\section{Struktura, źródła i odbiór społeczny wschowskiego kolędowania}

Według B. Ogrodowskiej, tradycyjny pochód kolędniczy, rozumiany jako rodzaj wędrownego teatru ludowego wywodzącego się z rolniczych obrzędów z maskami zwierzęcymi (maszkarami), składał się: na wsiach z grupek dzieci i młodzieży (przeważnie z najbiedniejszych domów) oraz młodych parobków, a w miastach - z ubogich terminatorów, czeladników,

9 Wszystkie wypowiedzi kolędników umieszczone w niniejszym artykule pochodzą z rozmów przeprowadzonych przeze mnie w latach 2015 i 2016 oraz z materiałów archiwalnych, które od nich uzyskałam. 
młodzieży z przedmieść i studentów ${ }^{\circ}$. Sama kolęda miała natomiast ustalony scenariusz:

Wchodząc do domu pozdrawiali gospodarzy, wygłaszali lub wyśpiewywali swe świąteczne i noworoczne życzenia powodzenia i urodzaju, a niekiedy odgrywali różne zabawne scenki, a nawet całe przedstawienia. Na koniec grzecznie prosili o datek. W świątecznym darze, zwanym kolędą, najczęściej otrzymywali jedzenie. [...] Z ukłonem za nie pięknie dziękowali i wychwalali hojnych gospodarzy ${ }^{\mathrm{II}}$.

Kolędniczy repertuar składa się zawsze z piosenki „na wejście”, pozdrowienia noworocznego, kilku kolęd, podziękowania i piosenki „na wyjście”. Piosenka „na wejście” śpiewana jest zaraz po otworzeniu drzwi przez gospodarza, aż do momentu, kiedy wszyscy kolędnicy znajdą się w jednym pomieszczeniu w środku (jeżeli gospodarz nie zaprosi kolędników do swojego domu, piosenka na wejście śpiewana jest krócej). Struktura dzieli się zatem na trzy części - mowę wstępną, fazę kolędowania i podziękowania. W mowie wstępnej kolędnicy recytują w ustalonej wcześniej kolejności swoje kwestie składające się na życzenia świąteczne (poniżej). Po złożeniu życzeń ma miejsce odśpiewanie kolęd. W trakcie śpiewu gospodarze mogą włożyć pieniężny datek do puszki trzymanej przez „Żyda”. Podarunki od domowników są różne. Zazwyczaj są to pieniądze, czasem jednak gospodarze częstują kolędników alkoholem i jedzeniem. Na koniec wizyty kolędnicy w formie podziękowania śpiewają piosenkę „na wyjście”, po czym wychodzą i kierują się do następnego domu. Plan działania kolędniczej akcji najlepiej obrazuje fragment okraszonej dozą humoru instrukcji kolędniczej, którą Komenda Głowna Koalicji Wschowskich Kolędników rozsyła każdego roku przygotowującym się do świąt kolędnikom:

Głównym założeniem naszych działań jest totalne zaskoczenie klienta. Klient ma nie wiedzieć co się dzieje, dlaczego przyszliśmy właśnie do niego i co mu chcemy zrobić. My wiemy to wszystko za niego. Podstawową naszą bronią jest determinacja - klient otworzywszy drzwi musi się ugiąć pod naporem naszej masy kolędniczej i wpuścić nas do środka. [...] Pamiętajmy, że (niestety) czas to pieniądz - w tym wypadku pieniądz, który może komuś choremu realnie pomóc. Nie może to jednak popychać nas w stronę odbębnionej tandety, która pozostawia tylko niesmak. Musimy być szybcy, zwięźli i na temat ${ }^{\mathrm{12}}$.

Io B. Ogrodowska, Polskie obrzedy i zwyczaje doroczne, Warszawa 2012, s. 43.

II Tamże.

I2 Instrukcja kolędnicza, archiwum autorki. 
Jak mówią członkowie Koalicji, z uwagi na niemal całkowite wyjałowienie tradycji kolędniczych na Ziemi Wschowskiej (o czym w dalszej części tekstu) zdecydowali się wzorować na innych. Połączenie wybranych elementów innych zwyczajów czyni działalność grupy tworem zupełnie nowym. W swojej formie najbardziej przypomina ona Herody - orszak kolędniczy znany na terenie prawie całej Wielkopolski ${ }^{\text {r3 }}$. W jej skład wchodzą bowiem Diabeł, Anioł, Śmierć, Żyd, Żołnierz, Gwiazdowy, Trzej Królowie, Cyganka oraz kilkoro Pasterzy ${ }^{14}$. Podczas pierwszych kolęd wymienionym postaciom towarzyszyli także Maryja i Józef, jednak pomysł ten nie przyjął się na dłuższą metę. Na przestrzeni kilkunastu lat padały różne propozycje, jak dołączenie szopki bożonarodzeniowej czy kukły turonia.

Muzyczny repertuar grupy również czerpie z różnych źródeł. Są wśród nich zarówno zasoby kultury tradycyjnej, jak i dorobek współczesnych zespołów muzycznych. Piosenka "na wejście” to utwór Życzenia z albumu Kolędy nagranego przez zespół Arka Noego w 2009 r. Część repertuaru stanowią także pieśni folkloru żywieckiego będące obok wielkopolskich Herodów główną inspiracją wschowskich kolędników. Spośród wielu materiałów wizualnych dostępnych w Internecie właśnie zwyczaje żywieckie są najatrakcyjniejszą inspiracją dla członków Koalicji. W związku z tym, że obrzędowość zimowa otwiera okres wegetacyjny, w obchodach bożonarodzeniowych znajdują się praktyki i treści związane z życzeniem pomyślnej wegetacji, urodzaju i płodnościrs. Ich relikty przetrwały do dzisiaj w wywodzeniu „po kolędzie” żywych zwierząt, obnoszeniu masek zwierzęcych i przedstawień $\mathrm{z}$ ich udziałem ${ }^{16}$. We Wschowie treści te obecne są również w pozdrowieniu noworocznym recytowane kolejno przez wschowskich kolędników. Jego słowa oparte są na kolędzie z terenów Beskidu Żywieckiego:

Na szczęście, na zdrowie, na Świętego Szczepana, co byście byli zdrowi, weseli jako w niebie anieli cały rok! / Co byście mieli pełne piwnice i pełne pudła! / Co

I3 A. Brencz, dz. cyt., s. 83 .

I4 Stereotypowe przedstawienia mniejszości religijnych i etnicznych w tradycyjnych obrzędach, w tym antysemickie wizerunki Żydów i rasistowskie Afroamerykanów, są, słusznie zresztą, zjawiskami kontrowersyjnymi i piętnowanymi. W 2019 r. decyzją Międzynarodowego Komitetu ds. Niematerialnego Dziedzictwa Kulturowego UNESCO za rasistowskie i antysemickie reprezentacje z Listy niematerialnego dziedzictwa kulturowego ludzkości usunięty został belgijski karnawał w Aalst. Źródło: https://en.unesco.org/news/aalst-carnival-removed-representative-list-intangible-cultural-heritage-humanity [dostęp: 9 czerwca 2020]. Jest to temat niezwykle istotny, jednak zbyt złożony, by poruszyć go w niniejszym tekście. Jego rzetelna analiza wymagałaby przeprowadzenia szerszych badań, nie tylko wśród samych kolędników, ale także innych mieszkańców miasta.

I5 B. Ogrodowska, Polskie obrzędy..., s. 44-45.

I6 Taż, Święta polskie..., s. 69. 
by wam gospodzina u pieca nie schudła! / Co byście mieli pieniędzy i nie zaznali nędzy! / Co byście mieli panny strojne i krowy dojne! / W każdym kątku po dzieciątku a na piecu troje! / A żebyście kolędy nie skąpili, to wam zaśpiewamy!

Zapożyczenie kolędniczego repertuaru z regionu Żywiecczyzny Koalicja zawdzięcza swojemu ,prezesowi”. To on szukał w sieci inspiracji w tradycyjnych pochodach kolędniczych z różnych regionów w Polsce. Zapytany o to, skąd pomysł na przeniesienie elementów tradycji żywieckich do Wschowy, mówi, że zależało mu na „porządnym i merytorycznie poprawnym kolędowaniu”. Obrzęd żywiecki był w jego oczach wzorem, który chciał odtworzyć we własnych warunkach.

Piosenką „na wyjście” najczęściej jest żywiecka pieśń ludowa $W$ lesie, $w$ lesie sosna rośnie, natomiast kolędy, które śpiewają wschowscy kolędnicy to najbardziej znane polskie pieśni: Aniot pasterzom mówit, Bóg sięrodzi,Dzisiaj w Betlejem, Gdy się Chrystus rodzi, Pójdźmy wszyscy do stajenki, Przybieżeli do Betlejem, Tryumfy Króla Niebieskiego czy W'śód nocnej ciszy. Zapytany o dobór kolęd „Król ze Wschodu” mówi: „Staramy się wybierać względnie te najbardziej znane, żeby ludzie mogli z nami śpiewać”.

Tym, co sprawia, że wizyta Koalicji Wschowskich Kolędników to niecodzienne doświadczenie, jest umiejętność gry wielu członków grupy na różnych instrumentach. Kolędnicy wykonują kolędy na wysokim poziomie muzycznym, ponieważ większość z nich ukończyła bądź wciąż uczy się w lokalnej szkole muzycznej. Niektórzy kontynuują edukację muzyczną w innych ośrodkach w kraju i za granicą. Wśród instrumentów, które na przestrzeni lat były wykorzystywane przez Koalicję, znalazły się: akordeon, trąbka, klarnet, skrzypce, saksofon, sakshorn, lira korbowa, bęben, cymbały, dzwonki, puzon i różnego rodzaju małe instrumenty perkusyjne, tzw. „przeszkadzajki”. Nie ma określonej ilości lub konkretnych instrumentów, na których muszą grać uczestnicy pochodu. Jak mówi jeden z kolędników, który od 2or r r. bierze udział w każdym kolędowaniu, „jeżeli pojawi się osoba, która na czymś gra, zawsze jest mile widziana”.

Kolędnicy najchętniej przyjmowani są w domach, gdzie mieszkają wielodzietne rodziny, ponieważ ich występ jest niecodzienną atrakcją dla dzieci. Zdarza się, że ze względu na dość głośną muzykę gospodarze nie wpuszczają kolędników. Grupa omija także te domostwa, które zamieszkiwane są przez osoby innego wyznania. Pytani o to, jak odbierane jest kolędowanie przez mieszkańców, kolędnicy odpowiadają jednak, że:

[...] w dziewięćdziesięciu procentach są to reakcje przyjazne. $\mathrm{Z}$ reguły widzimy też zaskoczenie. Ludzie są zadowoleni, dla dzieci to jest nowinka i zabawa, a starsze osoby zawsze się cieszą, że są ludzie, którzy kultywują tę tradycję. 
Głównie ludzie przyjmują nas serdecznie. Jedni bez zastanowienia wpuszczają do środka, innym razem śpiewamy przez domem. Zdarzało się też, że nie otwierano nam drzwi bądź sami kolędnicy omijali niektóre domy. Stali kolędnicy pamiętają z ubiegłych lat, gdzie na przykład mieszkają świadkowie Jehowy.

Inna wypowiedź: „Reakcje są zróżnicowane. Większość przychylna. Niektórzy wpuszczają do domu, inni nie. Niektórzy nie chcą wypuścić”.

Wynika z powyższego, że Koalicja Wschowskich Kolędników przemierza od kilku lat trasę niezmienioną, odwiedzając tych, którzy ich wizytę mają wpisaną w świąteczny harmonogram. Kolędnicy są „stałymi bywalcami” niektórych domów, podczas gdy do innych nie chcą bądź nie mają możliwości trafić.

Co sprawia, że każdego roku przybywa nowych kolędników? Członkowie grupy, z którymi rozmawiałam, dołączyli do Koalicji głównie z powodów towarzyskich. Większość z nich studiuje lub pracuje, często w różnych miejscowościach, toteż traktują kolędowanie jako okazję do spotkania i wspólnej zabawy. Dodatkową cechą działalności kolędników, która zachęca nowych członków, jest możliwość niesienia pomocy potrzebującym. Jeden z kolędników, zapytany o powody dołączenia do grupy, odpowiada: „Główny powód to moi bliscy znajomi, z którymi się już rzadko widuję, bo wszyscy są rozsiani po Polsce. A to jest dobry powód, żeby się spotkać. Oraz oczywiście możliwość pomocy komuś. Tym bardziej w fajny świąteczny czas".

Inna kolędniczka przyznała, że decyzję o dołączeniu do grupy podjęła ostatecznie po dwóch latach wahania, a czynnikiem wpływającym na jej motywację była zarówno możliwość spędzenia czasu ze znajomymi, jak i działanie charytatywne:

Z dwa lata czaiłam się na dołączenie do kolędników. Byli wśród nich moi znajomi i widziałam, ile radochy sprawia im całe przedsięwzięcie. Nie dość, że to doskonała zabawa w gronie kolegów, z którymi nie mamy okazji za często się widywać, to możemy też na swój wyjątkowy sposób przeżyć Boże Narodzenie i przy okazji cel zbiórki jest szczytny.

Powyższa wypowiedź wpisuje się w społeczną i wychowawczą funkcję obchodów kolędniczych. Jak zauważa B. Ogrodowska, dzięki nim mieszańcy danej miejscowości czuli się „moralnie zobowiązani do wspierania ubogich, zwłaszcza w okresie świątecznym” ${ }^{17}$. W odróżnieniu od dawnego kontekstu, 
o którym pisze badaczka, wschowscy kolędnicy nie zbierają datków dla siebie, lecz dla ustalonej rodziny w potrzebie. W niektórych przypadkach osobiste doświadczenie i przyjęcie grupy kolędniczej we własnym domu przyczyniło się do zaangażowania $\mathrm{w}$ obchody:

Już dwa, a może nawet trzy lata temu chciałam dołączyć, ale zawsze zwalałam na to, że nie umiem grać na instrumencie. A może po prostu brakowało mi odwagi? Kolędnicy byli u mnie w dwa tysiące czternastym roku i wtedy pomyślałam sobie, że nie ma to tamto, za rok idę z nimi.

Koalicja jest zatem dla jej uczestników miejscem spotkania, wspólnej zabawy, ale także formą przysłużenia się potrzebującym mieszkańcom miasta. Niewiele osób jako główną motywację dołączenia do grupy kolędniczej wskazywało zainteresowanie tradycjami kolędniczymi, czy chęć przyczynienia się do misji utworzenia nowej wschowskiej tradycji. Takie osoby stanowią wśród kolędników mniejszość, a są nimi ci, którzy od samego początku angażowali się w rozwój Koalicji. Oni przygotowują repertuar, szukają nowych inspiracji, pomagają przygotować stroje i potrzebne rekwizyty - gwiazdę, instrumenty, korony - i organizują w swoich domach próby. Dla innych kolędowanie wiąże się bardziej ze spotkaniem towarzyskim, co jednak nie czyni ich kolędnikami „drugiej kategorii”. Ostatecznie wszyscy poświęcają swój czas i wkładają w przedsięwzięcie tyle samo wysiłku. Wypowiedzi wschowskich kolędników wskazują na to, że czynnikiem wpływającym na podjęcie decyzji o dołączeniu do Koalicji jest chęć przynależności do grupy. $Z$ uwagi na tę społeczną potrzebę przynależności można rozważać zjawisko poprzez kategorię neoplemienności ${ }^{18}$. „Kolędnicze plemię" w znacznym stopniu tworzą absolwenci Szkoły Muzycznej I stopnia im. Karola Kurpińskiego we Wschowie oraz osoby z ich otoczenia w różnym wieku, choć najczęściej są to osoby w wieku między 20. a 30. rokiem życia. Grupa jest zatem oddolnym konstruktem społecznym wynikającym z wewnątrzpokoleniowej integracji lokalnej młodzieży i młodych dorosłych, nie zaś służącym do jej wytworzenia. Skomunikowanie się danej grupy społecznej i zawodowej jest z kolei, zdaniem Rocha Sulimy, zjawiskiem determinującym kształtowanie się folkloru ${ }^{19}$. Dionizjusz Czubala zauważa natomiast, że „jako produkt wynikający z wewnętrznej potrzeby grupy, folklor nie może być stymulowany z zewnątrz ani przez jednostki,

I8 M. Maffesoli, Czas plemion. Schytek indywidualizmu w spoteczeństwach ponowoczesnych, Warszawa 2008.

I9 R. Sulima, Folklor i literatura. Szkice o kulturze i literaturze wspótczesnej, Warszawa I985, s. 6. 
ani przez organizacje i instytucje" ${ }^{20}$. Koalicja Wschowskich Kolędników powstała z wewnętrznej potrzeby jej twórców, nie odgórnie narzuconego programu, choć instytucjonalne działania mają na nią wpływ. Działalność grupy promowana jest bowiem przez lokalne media oraz instytucje kultury. Gazety i portale internetowe („Słowo Ziemi Wschowskiej”, zw.pl, elka.pl) zamieszczają na swoich łamach zdjęcia i wywiady przeprowadzane z reprezentantami grupy. Znajdujące się w centrum miasta Muzeum Ziemi Wschowskiej informuje mieszkańców o naborze uczestników. Instytucja miała również bezpośredni udział w kolędzie - jedna z członkiń grupy była jednocześnie pracownicą muzeum. Również sami kolędnicy starają się popularyzować swoje przedsięwzięcie, prowadząc od kilku lat fanpage Koalicji na portalu społecznościowym Facebook ${ }^{21}$.

\section{Koalicja Wschowskich Kolędników na tle tradycji wielkopolsko-lubuskich}

Do Koalicji Wschowskich Kolędników dołączyłam nie tylko jako znajoma jej członków, ale również jako zainteresowana etnolożka. Od kilku lat słyszałam o występach tej grupy, jednak nigdy wcześniej nie byłam ich świadkiem. Obserwowałam pojawiające się w prasie artykuły oraz zdjęcia zamieszczane w Internecie. Zastanawiało mnie, skąd wzięła się we Wschowie taka grupa kolędnicza, kto i dlaczego ją utworzył?

Analizę wschowskich tradycji kolędniczych musi poprzedzić umiejscowienie Wschowy wraz z przylegającymi do niej wsiami na etnograficznej mapie Polski. Obszar ten stanowi rodzaj pogranicza, którego kategoryzacja wymyka się ustalonym w literaturze etnograficznej granicom regionów. Administracyjnie gmina i powiat wschowski od 1999 r. leżą w województwie lubuskim, przylegając do województwa wielkopolskiego i dolnośląskiego. Historyczne losy miasta i okolicznych wsi są jednak silnie zróżnicowane. Według niemieckiego historyka i badacza pogranicza śląsko-wielkopolskiego Martina Sprungali, pierwsza pośrednia wzmianka o Wschowie pochodzi z II36 r. z bulli papieża Innocentego II Ex comisso nobis do arcybiskupa gnieźnieńskiego Jakuba ze Żnina, gdzie została wskazana jako wieś należąca do archidiecezji. Powstała najprawdopodobniej na terenie Przyczyny Górnej i Dolnej, które dawniej zajmowały cały obszar współczesnej Wschowy ${ }^{22}$. W XIII w. wieś uzyskała prawa miejskie, stając się miastem należącym do Wielkopolski. W okresie rozbicia dzielnicowego miasto

\footnotetext{
20 D. Czubala, Opowieści ż̇ycia. Z badań nad folklorem wspótczesnym, Katowice 1985 , s. 60.

2I Adres Internetowy Grupy: https://www.facebook.com/koalicja.wschowskichkolednikow [dostęp: 6 czerwca 2020].

22 M. Sprungala, Kronika Wschowy, przeł. P. Zielnica, Dortmund-Wijewo 2016, s. II-I2.
} 
należało na zmianę do Piastów wielkopolskich i śląskich, a w styczniu 1793 r. wraz z otaczającymi ją wsiami zostało włączone do Prus. Po krótkiej przynależności do Księstwa Warszawskiego w latach 1807-I8Is ziemię wschowską ponownie przyznano Prusom i włączono w skład Wielkiego Księstwa Poznańskiego. Po odzyskaniu przez Polskę niepodległości w I9I8 r. na mocy traktatu wersalskiego większość powiatu wschowskiego została w granicach Niemiec (niem. Fraustadt). Stan ten utrzymał się aż do 1945 r., kiedy Wschowa i okolice znalazły się wśród tzw. Ziem Odzyskanych i zostały włączone w granice Polski. Podczas drugiej wojny światowej Wschowa, jako niemieckie miasto graniczne, została ostrzelana przez 55. Poznański Pułk Piechoty i 17. Pułk Ułanów, którzy podpalili dobytek mieszkańców i zabili trzech z nich. Dnia 20 I 1945 r. rozpoczęła się ewakuacja miasta. Uchodźcy trafili m.in. do Drezna, gdzie byli świadkami bombardowania. Stamtąd zostali ewakuowani do Chebu i Střibro w Czechach. W czerwcu 1945 r. na terenie Wschowy miały miejsce tzw. „dzikie wypędzenia” ostatnich niemieckich mieszkańców, które przeżyli nieliczni. W tym samym czasie do Wschowy dojeżdżały pierwsze wagony uchodźców z Kresów Wschodnich ${ }^{23}$. Na historię ziemi wschowskiej składają się zatem traumatyczne przeżycia ludzi obu narodowości. Więzy z ludnością pochodzenia niemieckiego nie zostały jednak całkowicie zerwane. Publikacje wspomnianego M. Sprungali są dwujęzyczne i dedykowane zarówno wszystkim mieszkańcom miasta, jak i członkom stowarzyszenia Freundeskreis Fraustadtere V. - niemieckiej organizacji, która zajmowała się badaniem historii Wschowy oraz gromadzeniem dokumentacji na jej temat. W latach 1976-1998 gmina Wschowa położona była w województwie leszczyńskim. Od 1999 r. miejscowość wraz z okolicznymi wsiami należy do województwa lubuskiego (w latach 1999-200I w powiecie nowosolskim, a od $2002 \mathrm{r}$. w powiecie wschowskim).

Przyczyna Górna i Dolna, które dzisiaj otaczają Wschowę, pierwotnie stanowiły jedną wieś, która po założeniu miasta podzieliła się na dwie części o różnych nazwach ${ }^{24}$. Przyczyna Górna to jedna z najstarszych miejscowości ziemi wschowskiej, która w 2010 r. obchodziła swoje $800-l e c i e^{25}$. Pierwsza część nazwy wsi, tłumaczona jako „przydatek, dodatek, przydziałek", miała sugerować jej związek z miastem. Druga mogła zawierać informację o gospodarczym statusie miejscowości. W pochodzącym z I404 r.

\footnotetext{
23 Tamże, s. 379-380.

24 M. Sprungala, Wsie i miasta na pograniczu gtogowsko-wielkopolskim. Zarys dziejów wybranych miejscowości, przeł. P. Zielnica, Dortmund-Wijewo 2018, s. 378.

25 Tenże, Kronika..., s. I2.
} 
przywileju króla Jagiełły do określenia Przyczyny Górnej i Dolnej użyto przymiotników supieror i inferior ${ }^{26}$. „Górna” to, podobnie jak Wschowa, miejscowość o bogatej historii silnie związanej z procesami przesiedleńczymi. Od początku Przyczynę Górną (niem. Ober-Pritschen) zamieszkiwała ludność pochodzenia niemieckiego. XVI-wieczne ewangelickie księgi kościelne oraz akta Komisariatu Obwodowego Wschowa-Północ z Archiwum Państwowego w Zielonej Górze wskazują takie nazwiska, jak Berger, Glatzer, Heinrich, Schneider czy Zügler. Niektóre budynki należały jednak do rodzin o polskim nazwisku, m.in.: Franciskowski, Skrzypkowiak i Szymanski. Uciekając przed frontem, wszyscy opuścili swoje domy, które zajęli Polacy - początkowo osadnicy z województwa poznańskiego, później repatrianci z Kresów Wschodnich. W budynku dawnej szkoły ewangelickiej powstała polska szkoła podstawowa, której kierownikiem został repatriant z Trembowli (woj. tarnopolskie) ${ }^{27}$. Urząd pierwszego soltysa w powojennej Przyczynie Górnej objął natomiast repatriant z Wileńszczyzny. W pozostawionym przez Niemców dworze $\mathrm{z}$ folwarkiem powstał Państwowy Ośrodek Hodowli Zarodowej Osowa Sień, który przejął także zespół pałacowo-parkowy położony przy drodze do Tylewic ${ }^{28}$. Innym zabytkiem na terenie miejscowości jest kościół pod wezwaniem św. Jerzego z drugiej połowy XIV w., zwany później „Czerwonym Kościołem” ${ }^{29}$. Pod koniec XIX w. odkryto w nim XV-wieczne gotyckie freski przedstawiające m.in. sceny $z$ historii syna marnotrawnego, wizerunki Adama i Ewy przy drzewie oraz siedem grzechów głównych. We wsi funkcjonuje Ochotnicza Straż Pożarna zorganizowana na przełomie lat 40. i 50 . XX w., Koło Gospodyń Wiejskich założone w 1958 r. oraz sala wiejska, w której mieszkańcy organizują zarówno prywatne imprezy okolicznościowe (wesela, komunie, chrzciny), ogólnodostępne zabawy towarzyskie (bale karnawałowe, festyny) jak i formalne spotkania (zebrania Rady Sołeckiej). W I954 r., po zlikwidowaniu gmin, Przyczyna Górna została włączona wraz z Łysinami i Wygnańczycami do gromady Tylewice. Po przywróceniu wcześniejszego

26 Tamże, s. 30 .

27 W roku 200 Rada Miasta i Gminy Wschowa podjęła uchwałę o likwidacji szkoły. Decyzji tej sprzeciwili się mieszkańcy miasta, którzy w celu przywrócenia placówki założyli Stowarzyszenie na rzecz Ekorozwoju Wsi „Nasze Dzieci”. Członkowie stowarzyszenia przejęli i wyremontowali budynek, a następnie otworzyli Niepubliczną Szkołę Podstawową w Przyczynie Górnej. W 2017 r., z uwagi na brak funduszy na wynagrodzenie dla nauczycieli oraz niewielką liczbę uczniów, szkołę ponownie zamknięto.

28 Obecnie budynek należy do przedsiębiorstwa Hodowla Zwierząt Zarodowych Osowa Sień Sp. z o.o., które współcześnie należy do wiodących producentów bydła mlecznego w Polsce. W latach 80. XX w. obiekt przebudowano, a po roku 2000 wyremontowano elewację.

29 M. Sprungala, Kronika..., s. 27. 
podziału administracyjnego niecałe dwadzieścia lat później wieś weszła w skład gminy Przyczyna Dolna. Od lat 70. Xxw. miejscowość stanowi solectwo w ramach Miasta i Gminy Wschowa.

Drugą z przylegających do Wschowy wsi jest Przyczyna Dolna (niem. Nieder-Pritschen). To miejscowość mniejsza niż Przyczyna Górna, położona znacznie bliżej centrum miasta. M. Sprungala wskazał, że w $1315 \mathrm{r}$. Wschowa wykupiła na wsi pierwsze połacie dóbr szlacheckich, w wyniku czego Przyczyna Dolna stała się wsią podmiejską $3^{30}$. W połowie XV w. Kazimierz IV Jagiellończyk nadał wsi prawa sołtysa. Działały w niej dwa majątki ziemne: Folwark Srodkowy ze słodownią oraz Folwark Dolny ${ }^{31}$. W latach 1958-1973 stanowiła siedzibę lokalnej gromady, czyli najmniejszej jednostki podziału terytorialnego Polskiej Rzeczypospolitej Ludowej. Po reformie gminnej z 1973 r. w miejscu dawnej gromady utworzono gminę Przyczyna Dolna, która istniała trzy kolejne lata. W styczniu 1976 r. organy władzy i administracji państwowej zostały przeniesione stamtąd do Wschowy. Obecnie Przyczyna Dolna funkcjonuje raczej jako dzielnica Wschowy, niż osobna miejscowość. W przeciwieństwie do Przyczyny Górnej nie posiadała własnej szkoły, a z uwagi na brak własnego kościoła jej życie religijne odbywa się w mieście. Współcześnie nie działa tam Koło Gospodyń Wiejskich ani Ochotnicza Straż Pożarna. We wsi swoją siedzibę ma natomiast wiele firm o różnych profesjach, m.in. ferma drobiu, hurtownia artykułów papierniczych, produkcja metalowa czy wulkanizacja.

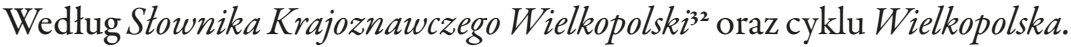
Nasza kraina ${ }^{33}$ okolice Wschowy stanowią zachodnie rubieże Ziemi Lubuskiej. W książce Wielkopolska jako region etnograficzny A. Brencz umieszcza mapy dokumentujące pracę badaczy Atlasu jezyka i kultury ludowej Wielkopolski oraz Kultury Ludowej Wielkopolski, na których co prawda widnieje Wschowa, jednak nie objęły jej badania terenowe ${ }^{34}$. Jeszcze inną perspektywę przyjęli autorzy Ziemi Lubuskiej - pierwszej i jak do tej pory jedynej tak obszernej pracy zbiorowej poświęconej tzw. Ziemiom Odzyskanym. Opisali okolice Wschowy jako część Krainy Międzyrzeckiej, stanowiącej subregion Ziemi Lubuskiej35. Była dyrektor Muzeum Ziemi Wschowskiej $\mathrm{w}$ rozmowie na temat niematerialnego dziedzictwa kulturowego regionu

\footnotetext{
30 Tamże, s. 17.

3I M. Sprungala, Wsie i miasta..., s. 378.

32 W. Łęcki, Stownik Krajoznawczy Wielkopolski, Warszawa-Poznań 1992.

33 W. Łęcki, Wielkopolska. Nasza Kraina, Poznań 2004.

34 A. Brencz, Wielkopolska jako region etnograficzny, Poznań 1996.

35 Ziemia Lubuska, red. M. Sczaniecki i S. Zajchowski, Poznań ı950, s. 7.
} 
stwierdziła, że „historycznie jest to Wielkopolska, bez dwóch zdań. Po wojnie w tym odradzającym się mieście administrację tworzyli głównie Wielkopolanie - urzędnicy w większości z sąsiedniego województwa. Wschowę należy jednak jak najbardziej zaliczyć historycznie do Wielkopolski”. Skomplikowanej historii miasta są świadomi jego mieszkańcy. W monografii poświęconej lokalnemu oddziałowi Banku Spółdzielczego, który działa nieprzerwanie od 1947 r., czytamy, że „we Wschowie na wiek Banku trzeba patrzeć inaczej, bo miasto jest wyjątkowe. [...] Niemal dziesięciowiekowa historia Wschowy [...] jest skomplikowana: zmiany władców, przynależności państwowej, składu narodowościowego jej obywateli spowodowały, że trudno jednoznacznie powiedzieć, co w obecnym czasie wynika i z której tradycji pochodzi, a co jest czymś całkowicie nowym" ${ }^{36}$. Cytat ten wpisuje się także w rozważania nad wschowskim kolędowaniem.

Kluczowym jest, że ziemia wschowska to tereny o przerwanej ciągłości kulturowej. Dawną ludność dzisiejszego powiatu wschowskiego stanowili Niemcy, Polacy i Żydzi. Społeczno-kulturowa rzeczywistość Wschowy zmieniła się w wraz z niemal całkowitą powojenną wymianą ludności miasta. W I944 r., na mocy umowy zawartej pomiędzy Rzeczpospolitą Polską reprezentowaną przez Edwarda Osóbkę-Morawskiego a Związkiem Radzieckim reprezentowanym przez Wiaczesława Mołotowa, doszło do przesunięcia jej granic, a rzesze ludzi zasiedlających wschodnie rubieże II Rzeczypospolitej znalazły się w ZSRR. Na podstawie umów polsko-radzieckich z 1944 r. ludność z Kresów Wschodnich przesiedlono na ziemie inkorporowane do Polski po jej zachodniej stronie. Przesiedlenia Polaków wiązały sięz jednoczesnym opuszczeniem tych terenów przez ich dotychczasowych mieszkańców, czyli w większości ludności pochodzenia niemieckiego ${ }^{37}$. Do opuszczonych przezNiemców domów i mieszkań zaczęli wprowadzać się nowi mieszkańcy, sprowadzeni z byłych rubieży wschodnich II Rzeczypospolitej. Kresowianie, stanowiący dzisiaj większość mieszkańców Wschowy, przywieźli ze sobą swoje własne doświadczenia, a wraz z nimi obrzędy i zwyczaje. Utarło się we Wschowie powiedzenie, że nie ma wśród mieszkańców Wschowy nikogo, kto nie miałby w rodzinie krewnego z Kresów. Dotyczy to także mojej rodziny. Moi pradziadkowie ze strony ojca pochodzili ze wsi Dołżanka i miasta Czortków - obie miejscowości znajdują się dzisiaj na Ukrainie, w województwie tarnopolskim. Do dzisiaj na Wigilię szykujemy kutię - tradycyjną potrawę kuchni wschodniej (ukraińskiej, białoruskiej, rosyjskiej i litewskiej) z gotowanej pszenicy, miodu i maku.

36 Bank Spótdzielczy we Wschowie 1947-2017, Warszawa 2017, s. 7.

37 Przesiedlenie ludności polskiej z Kresów Wschodnich do Polski 1944-1947. Wybór dokumentów, red. S. Ciesielski, Warszawa 2000 , s. I3. 
Powojenną ludność miasta i okolicznych wsi nie stanowili jednak wyłącznie Kresowianie. Do Wschowy migrowali również mieszkańcy Polski centralnej, m.in. Wielkopolanie i Małopolanie ${ }^{38}$. Wschowa, Przyczyna Górna i Dolna stanowią zatem swoisty konglomerat złożony ze zróżnicowanych doświadczeń i wzorów kulturowych. Warto jednak zaznaczyć, że wszystkie badania, na podstawie których powstały książki, do których odnoszę się w niniejszym artykule, zostały przeprowadzone w drugiej połowie XX w., a zatem już po największych przesiedleniach ludności kresowej - zawarty w nich materiał empiryczny zebrany został wśród powojennej ludności ziemi wschowskiej. W Wielkopolsce kolęda oznaczała zwyczaj obchodzony między Nowym Rokiem a świętem Trzech Króli. Jak pisze Józef Burszta:

Wieczorem zbierali się ludzie dworscy i z włodarzem na czele szli pod dwór. Włodarz niósł latarkę, dzwonek i stare wydanie kantyczek [zbiór kolęd wydany w formie książkowej - przyp. K.D.]. [...] Po odśpiewaniu około dziesięciu kolęd otrzymywali od dziedzica kolędę, czyli pieniądze, i szli się zabawić. Po kolędzie chodziły także dzieci. [...] Po odśpiewaniu czterech, pięciu kolęd dzieci otrzymywały pieniądze i szły dalej. [...] Po godzinie 22 chodzili po wsi starsi chłopacy i śpiewali pod domami kolędy, a za uzbierane pieniądze szli się zabawič39.

Z ustaleń J. Burszty wynika, że kolędowanie oznacza obchodzenie wsi połączone ze śpiewaniem pieśni bożonarodzeniowych wraz ze składaniem życzeń noworocznych rolnikom. Badacz ten widzi także w kolędzie element charakterystyczny dla wszystkich zwyczajów przedchrześcijańskich - wspólną zabawę i ucztę uczestników obrzędu. Opisy zwyczajów kolędowania w Kulturze Ludowej Wielkopolski pochodzą jednak z miejscowości oddalonych od Wschowy o kilkadziesiąt, a nawet kilkaset kilometrów (Nowe Kramsko, powiat zielonogórski; Siemianice, powiat kępiński). A. Brencz w Wielkopolskim roku obrzędowym pisze z kolei o gwiazdorach i gwiazdkach, którzy jako grupa kolędnicza występowali niegdyś w południowej Wielkopolsce. W dzisiejszych czasach jednak zwyczaje kolędnicze nie są już praktykowane - w okresie świątecznym w Wielkopolsce domy odwiedza głównie gwiazdor. Autor wspomina jednak o zachowanej i praktykowanej do dzisiaj w Bukówcu Górnym (powiat leszczyński) lokalnej tradycji gwiazdora, gwiazdki i diabła - grupy kolędniczej zachodzącej do domów, pytającej dzieci o dobre zachowanie i śpiewającej kolędy. Bukówiec Górny oddalony jest od Wschowy o 20 km - bliżej niż miejscowości

38 B. Ratajewska, Materiaty archiwalne dziejów Wschowy, Leszno 2013, s. 47.

39 Kultura Ludowa Wielkopolski, red. J. Burszta, Poznań 1967, s. 25-28. 
wymienione w Kulturze Ludowej Wielkopolski. Nie ma jednak żadnych informacji mówiących o gwiazdorach i gwiazdkach w okolicach samej Wschowy. Autorzy Ziemi Lubuskiej wydanej w I950 r. zauważyli, że w literaturze naukowej brakuje pozycji poświęconych temu regionowi. Według nich:

Ziemia Lubuska to teren nieznany. Nie budził on zainteresowań uczonych niemieckich, nie zajmowali się nim dotąd uczeni polscy. Kraj niewielki, o zmiennych granicach, nie należący prawdziwie ani do Wielkopolski, ani do Brandenburgii, ani do Śląska, ani do Pomorza, uległ niemal całkowitemu zapomnieniu ${ }^{40}$.

Mając na celu uzupełnienie braków w naukowej wiedzy na temat tzw. Ziem Odzyskanych, grupa badaczy specjalizujących się w różnych dziedzinach naukowych przeprowadziła kompleksowe badania nad historią, geografią i kulturą regionu. Autorzy wprowadzili w książce podział Ziemi Lubuskiej na cztery mniejsze regiony: krainę torzymską, gorzowską, krośnieńską i międzyrzecką. Powiat wschowski wchodzi zgodnie z tym podziałem w skład ostatniej z krain, obok powiatów: skwierzyńskiego, międzyrzeckiego i babimojskiego. Etnografka Anna Kutrzebianka w rozdziale Lud i jego zwyczaje opisuje chodzących po wsiach w okresie świątecznym gwiazdorów i gwiazdki. Obie postacie odgrywane są przez młodych chłopców - gwiazdor w kożuchu założonym na lewą stronę i z umalowaną na czarno twarzą, gwiazdka w białej sukni i tiulowej chustce ${ }^{41}$. Żadna z miejscowości, w których badacze odnaleźli taki zwyczaj, nie leży w pobliżu Wschowy. Podobnie jak w Kulturze Ludowej Wielkopolski jest to Kramsk oraz Nowe Kramsko w powiecie zielonogórskim, natomiast opis dotyczący samej Wschowy ogranicza się jedynie do jej architektury ${ }^{42}$. W 7. tomie Komentarzy do Polskiego Atlasu Etnograficznego dotyczącym pomocy wzajemnej i współdziałaniu sąsiedzkiemu m.in. w obrzędowości dorocznej pojawia się tylko wieś Wróblów - położona co prawda $\mathrm{w}$ powiecie wschowskim, ale w innej gminie (Sława). Tam zaobserwowano zwyczaj obdarowywania kolędników jajkami i mąkąa ${ }^{43}$. Nie znajdziemy natomiast żadnej miejscowości z gminy Wschowa ${ }^{44}$.

Z uwagi na zawiłości historyczno-terytorialne pytanie o przynależność Wschowy do konkretnego regionu etnograficznego zdaje się właściwie

\footnotetext{
40 Ziemia Lubuska..., s. 208-210.

4I Tamże, s. 167-189.

42 Tamże, s. 222.

43 A. Drożdż, Pomoc wzajemna. Wspótdziatanie spoteczne i pomoc sąsiedzka. Komentarze do Polskiego Atlasu Etnograficznego, t. VII. red. Z. Kłodnicki, Wrocław-Cieszyn 2002, s. 280.

44 Wschowa, Przyczyna Górna, Przyczyna Dolna, Olbrachcice, Łęgoń, Wygnańczycze, Konradowo, Kandlewo, Siedlnica, Nowa Wieś, Nowe Ogrody, Osowa Sień, Dębowa Łęka, Lgiń, Hetmanice, Tylewice.
} 
pytaniem o poczucie tożsamości regionalnej. Jak zauważa A. Brencz, prócz odrębności formalnych cech kultury istotnym kryterium wyznaczania granic regionów jest świadomość jego mieszkańców i wykształcenie wśród nich poczucia odrębności regionalnej i identyfikacji z regionem ${ }^{45}$. Była dyrektor wschowskiego muzeum, zapytana o obecność Wielkopolski w świadomości mieszkańców regionu, stwierdziła, że:

taka jest prawda historyczna, ale ciekawie byłoby zobaczyć, jakie jest poczucie tożsamości. Trzeba by było po prostu przeprowadzić wywiady. Sama jestem ciekawa tych odpowiedzi. Ja mogę odpowiedzieć, kim ja się czuję. Jestem osobą urodzoną już we Wschowie i przede wszystkim czuję się wschowianką. Prawda jest jednak taka, że moje korzenie ze strony matki sięgają Wielkopolski, do niedalekich Włoszakowic, ze strony ojca natomiast sięgają do Kresów. To jest, można powiedzieć, podwójna tożsamość, złożona tożsamość, bo na pewno coś takiego jest.

Badaczka huculskiej tradycji kolędniczej Justyna Cząstka-Kłapyta uważa, że w ludowej twórczości można wyróżnić dwa rodzaje uczenia muzycznego - w kontekście naturalnym oraz w procesie wyuczenia. Wśród badanych przez nią huculskich kolędników nauka repertuaru obrzędowego wiąże się często z normami społecznymi i obrzędowymi, które wymagają poznania rodzimej tradycji muzycznej ${ }^{46}$. Wśród wschowskich kolędników nie zaobserwowałam takiej praktyki. Członkowie Koalicji dołączają do niej zachęcani przez znajomych, ale nie na skutek zinternalizowanego, przekazywanego w rodzinie od pokoleń obrzędowego obowiązku. Grać na swoich instrumentach nie uczą się też ze słuchu (czyli, według J. Cząstki-Kłapyty - naturalnie), ale najczęściej w miejscowej szkole muzycznej w sposób odgórnie określony i kontrolowany. Zorganizowane i uświadomione zmiany w obrzędowości - takie jak właśnie wyuczanie repertuaru kolędniczego, a nie poznawanie go w naturalnym kontekście - funkcjonują, według J. Cząstki-Kłapyty, raczej jako „tradycja wynaleziona” ${ }^{47}$. Termin ten wprowadzili do humanistyki historycy Eric Hobsbawm i Terence Ranger, określając w ten sposób symbole narodowe odwołujące się do zamierzchłych czasów oraz rytuały prezentowane jako dawne tradycje, które w rzeczywistości mają dużo krótszy rodowód, a które zostały wynalezione w celu utworzenia określonej tożsamości narodowej ${ }^{48}$. Według badaczy, zjawisko tworzenia się nowych

45 A. Brencz, Wielkopolskajako region..., s. 30-31.

46 J. Cząstka-Kłapyta, Kolędowanie na Huculszczyźnie, Kraków 2014, s. 234.

47 Tamże, s. 234-236.

48 E. Hobsbawm, T. Ranger, Tradycja wynaleziona, przeł. M. Godyń, F. Godyń, Kraków 2008. 
tradycji zachodzi najczęściej tam, gdzie miały miejsce gwałtowne zmiany społeczne - żniwo drugiej wojny światowej w postaci masowych przesiedleń bez wątpienia jest takiego rodzaju zmianą. E. Hobsbawm w ramach procesów wynajdywania tradycji zwraca także uwagę na sztuczny związek teraźniejszości z przeszłością. W przypadku wschowskich kolędników czynnikiem wytwarzającym taki związek są apelujące o ochronę zanikającej tradycji wypowiedzi członków grupy czy sporządzane przez nich kolędnicze instrukcje, poprzez które adepci kolędniczy przyuczani są do nadchodzącej akcji. Założenia Koalicji, czyli chęć ujednolicenia praktyk kolędniczych na terenie powiatu wschowskiego poprzez organizację warsztatów doszkalających inne grupy kolędników również wskazuje na proces tworzenia i rozwijania się tejże tradycji. Jak zauważyła zresztą A. Zadrożyńska, współczesne i tradycyjne formy świętowania kształtowane są przez własne oryginalne pomysły twórców, spotkania, wymiany, wybory i zapożyczenia ${ }^{49}$.

\section{Czy wschowskie kolędowanie jest tradycją?}

Etnograficzna dokumentacja obrzędów i zwyczajów dorocznych w Wielkopolsce i na Ziemi Lubuskiej wskazuje na to, że na terenie ziemi wschowskiej kolędowanie prawie nie występowało. Niemożliwym był więc jej przekaz międzypokoleniowy, który stanowi najistotniejszy wyznacznik tradycji w rozumieniu m.in. Zbigniewa Jasiewicza ${ }^{50}$, J. Burszty ${ }^{51}$ czy Jerzego Szackiego $^{52}$. Praktyka kolędowania we Wschowie i okolicznych wsiach, jej forma i treść, została jednak zapożyczona, a nie przekazana. Z uwagi na to, że nie jest dziedziczona, nie wpisuje się również w kategorię dziedzictwa kulturowego, rozumianego przez Narodowy Instytut Dziedzictwa jako zespół praktyk, wyobrażeń, przekazów, wiedzy i umiejętności przekazywanych z pokolenia na pokolenie, odtwarzanych przez kolejnych depozytariuszy i dających poczucie określonej tożsamości ${ }^{3}{ }^{3}$. Również sami kolędnicy mówili, iż do grupy dołączyli nie ze względu na obecną w lokalnym krajobrazie kulturowym tradycję kolędniczą, a chęć wspólnego spędzania czasu ze znajomymi, sprawiania radości odwiedzanym osobom, a przy okazji również niesienia pomocy.

49 A. Zadrożyńska, Powtarzać czas..., s. 9.

50 Z. Jasiewicz, Tradycja, [w:] Stownik etnologiczny. Terminy ogólne, red. Z. Staszczak, Warszawa-Poznań 1987 , s. 354-358.

5I J. Burszta, Kultura ludowa - kultura narodowa. Szkice i rozprawy, Warszawa 1974, s. 342.

52 J. Szacki, Tradycja. Przeglad problematyki, Warszawa 1971, s. 97-98.

53 Definicja niematerialnego dziedzictwa kulturowego na stronie Narodowego Instytutu Dziedzictwa, http://niematerialne.nid.pl/Dziedzictwo_niematerialne/ [dostęp: I2 kwietnia 2017]. 
Nie bez znaczenia jest tutaj jednak fakt, że Wschowa to miasto, które po drugiej wojnie światowej uległo niemal całkowitej wymianie ludności spowodowanej przesiedleniami Niemców i Polaków z Kresów Wschodnich. Przerwana ciągłość kulturowa nie dała więc szansy na zakorzenienie się w tym miejscu elementów kultury tradycyjnej takich jak zwyczaje świąteczne, a już na pewno nie w takim stopniu, jak ma to miejsce w innych regionach Polski. Niewykluczone, że właśnie to zadecydowało o pomijaniu miasta w etnograficznych badaniach nad materialnym i niematerialnym dziedzictwem kulturowym Wielkopolski. Najprawdopodobniej właśnie w okolicach Tarnopola, skąd pochodzi większość obecnych mieszkańców Wschowy, kolędnicy powinni szukać inspiracji do swoich praktyk - być może dosłownie, udając się w tamte tereny, ale głównie poprzez wydobycie wspomnień o kolędowaniu $\mathrm{z}$ pamięci osób przesiedlonych. $\mathrm{xX}$-wieczne przesiedlenia są również punktem wyjścia do pogłębienia badań nad kolędowaniem we Wschowie. Wbrew temu, co wykazali przywołani wyżej etnografowie, podczas naszego kolędowania wiele osób mówiło o dawnych pochodach kolędniczych, których byli świadkami. Z perspektywy antropologicznej nieścisłość ta może być interesującym przedmiotem badań. Dwukrotna obserwacja uczestnicząca to jednak w dalszym ciągu za mało do tego rodzaju analizy. W tym kontekście niezbędne jest przeprowadzenie szeroko zakrojonych badań, które skupiałyby się na sprawdzeniu dokładnego pochodzenia informatorów.

Choć trudno ją dostrzec, istnieje także pewna analogia pomiędzy wschowskim kolędowaniem a wynajdywaniem kultury u Maorysów, które opisał Allan Hanson ${ }^{54}$. Maorysi bowiem, jak uważa badacz, tworzyli swoją kulturę przez okres ostatnich ponad stu lat, a źródłem procesu wynalazczego były m.in. antropologiczne interpretacje badaczy poszukujących ich pochodzenia. Mimo wątpliwej naukowej wiarygodności narracji o „Wielkiej Flotylli” i kulcie Io, Maorysi przyjęli je jako autentyczne i włączone do ich kulturowego dziedzictwa, a kultura powstała na skutek tego wyobrażenia służy im za podstawę projektu tożsamościowego, budowanego w opozycji do Pakeha - mieszkańców Nowej Zelandii o niemaoryskim pochodzeniu. Wprawdzie kolędowanie we Wschowie nie implikuje aż tak daleko idących konsekwencji, można znaleźć pewne podobieństwo. Koalicja Wschowskich Kolędników, podobnie jak niegdyś Maorysi, zaczerpnęła z zewnątrz inspiracji do swojej działalności. Wybrane elementy folkloru Żywiecczyzny i Północnej Wielkopolski stanowią dziś podstawę wschowskiej kolędy.

54 A. Hanson, Kreowanie Maorysa, wynalazek kultury i jego logika, przeł. J. Schmidt, [w:] Amery-

kańska antropologia postmodernistyczna, red. M. Buchowski, Warszawa 1999, s. 183-201. 
Sami kolędnicy rzecz jasna mają tego świadomość (mogą przeczytać o tym w instrukcji kolędniczej), pytanie tylko, czy odbiorcy również?

Czerpanie inspiracji z różnych tradycji regionalnych w Polsce nadaje wschowskiemu kolędowaniu charakter folkloryzmu - w takim sensie, w jakim ujął to zjawisko J. Bursztas - stosowania w szczególnych sytuacjach życiowych wybranych treści i form folkloru w postaci wtórnej i w sytuacjach zazwyczaj celowo zaaranżowanych. Koalicja Wschowskich Kolędników zmienia się bowiem nawet każdego roku - w zależności od potrzeb swoich lub w odpowiedzi na potrzeby mieszkańców miasta kolędnicy zmieniają bądź uzupełniają swój repertuar i wygląd. Jeszcze kilka lat temu wśród przebierańców znajdowali się Maryja z Józefem, próbowano wprowadzić noszenie bożonarodzeniowej szopki, ponadto w planach grupy jest także uzupełnienie grupy o postać turonia. Elementy polskich tradycji kolędniczych są zatem traktowane wybiórczo, dopasowywane do aktualnych potrzeb i możliwości. Z drugiej jednak strony, nie zmieniają one swojego pierwotnego znaczenia - są wyjęte jedynie z kontekstu geograficznego. Pieśni z dorobku tradycyjnej kultury żywieckiej śpiewane przez kolędników, czy postacie z wielkopolskich Herodów, za które się przebierają podczas świątecznych występów, nie są bowiem zmieniane, to raczej bezpośrednia inspiracja innymi tradycjami kolędniczymi. Są zwyczajami przejętym od innych grup społecznych, w których uznane są one za tradycyjne. Nie dochodzi zatem do tego, co J. Burszta określił jako immanentną cechę folkloryzmu, czyli prezentowania zapożyczonych form w postaci zmienionej, oderwanej od swojego pierwotnego znaczenia. Biorąc pod uwagę główną motywację dołączania moich rozmówców do grupy kolędniczej, jaką jest możliwość spędzania czasu ze znajomymi, zwykle przy alkoholu, można skonkretyzować to wydarzenie jako rodzaj folkloryzmu obrzędowego w formie towarzyskiej zabawy. J. Burszta określa tym mianem większość obrzędów cyklu dorocznego odtwarzanych przez młodzież, które nierzadko poprzedzane są stosownymi pouczeniami (badacz pisze m.in. o poradnikach obrzędowych wydawanych w Centralnej Poradni Amatorskiego Ruchu Artystycznego) mówiącymi o tym, jak powinno się obchodzić dane święto ${ }^{56}$. Członkowie Koalicji także sporządzili takiego rodzaju pouczenie, ponadto mają w planach organizować warsztaty uczące „niewykwalifikowanych” kolędników.

Jednocześnie przez samych członków grupy i społeczność wschowską ich działalność określana jest mianem tradycyjnej. Na podstawie narracji

55 J. Burszta, Folkloryzm, [w:] Stownik etnologiczny..., 142-143.

56 Tenże, Kultura ludowa - folkloryzm - kultura narodowa, „Kultura i Społeczeństwo” ${ }_{1969,}$ nr 4 (I3), s. 84. 
kolędników, reakcji mieszkańców, którzy gościli ich w swoich domach czy materiałów umieszczanych w lokalnej prasie można rozpatrywać tę tradycyjność na dwóch poziomach - lokalnym i ponadregionalnym. Zarówno w wypowiedziach ludzi, jak i w artykułach prasowych, pojawiały się równolegle dwa określenia: wschowska oraz (zanikająca) polska tradycja kolędnicza. Przykładowo - w 2013 r. portal zw.pl opublikował wywiad z Koalicją, w którym napisano, że „25 grudnia 2013 po raz kolejny rusza Tradycyjna Wschowska Kolęda - akcja mająca na celu podtrzymanie ginącej tradycji kolędowania"s7. Równolegle w swoich narracjach kolędnicy odwołują się do polskiej tradycji kolędniczej, którą poprzez swoje działania chcą ocalić od zapomnienia i zakorzenić w swoim miejscu zamieszkania. Być może ma tutaj miejsce czerpanie z tzw. polskiego folkloru narodowego, czyli - jak odnotowuje J. Burszta ${ }^{58}$ - jednolitego nurtu folklorystycznego powstałego z tendencji łączenia typowych i najbardziej atrakcyjnych dla widza elementów różnych folklorów, traktowanego jako wspólne dobro wszystkich obywateli. Jak również w tym kontekście zauważają redaktorzy Atlasu Niematerialnego Dziedzictwa Kulturowego Wsi Wielkopolskiej:

Dziedzictwo, tak jak tradycja, coraz silniej traci na swej autentyczności. [...] Przeciętny użytkownik nie żyje w jednej, ale w wielu kulturach: lokalnej, krajowej (narodowej) i w dużej części globalnej. Jego dziedzictwem są zarówno wigilijny stól, jak i ulubiona piosenka nieistniejących od dekad Beatlesów9.

W związku z tym oraz z braku kolędniczych pierwowzorów lokalnych Koalicja inspiruje się tradycjami z różnych zakątków kraju. Jej pomysłodawcy posiadali pewne wyobrażenie na temat tradycyjnego kolędowania, które chcieli zaimplementować we własnym krajobrazie kulturowym. Tym samym uznają siebie za grupę kolędniczą, która jest tradycyjna - opierająca się na tradycyjnym folklorze (niezależnie jakim), rzetelna - będąca efektem wielu starań, prób i umiejętności muzycznych, oraz poprawna merytorycznie - zgodna ze źródłami zastanymi. Taki sposób postrzegania tradycji rozmija się z naukowym, etnologicznym rozumieniem tego terminu, które zasadza się na bezpośrednim przekazie międzypokoleniowym. W tym znaczeniu tradycja jest kategorią badawczą, która pozwala na kategoryzację i analizę zaobserwowanych w terenie praktyk społecznych. We wschowskim kolędowaniu

57 Nadciaga Koalicja Wschowskich Kolędników, http://zw.pl/news/nadciaga-koalicja-wschowskich-kolednikow-,46013 [dostęp: 6 czerwca 2020].

58 J. Burszta, Kultura ludowa - folkloryzm..., s. 90.

59 A.W. Brzezińska, A. Jełowicki, W. Mielewczyk, Zatożenia, metodyka, cele. Atlas niematerialnego dziedzictwa kulturowego wsi wielkopolskiej, t. I, Szreniawa 2015, s. 2 I. 
"tradycyjność" odnosi się do warstwy estetycznej folkloru i artystycznego o nim wyobrażenia, nie zaś do procesu dziedziczenia. Można by w tym miejscu zadać pytanie podobne do tego, które postawił Mikołaj Smykowski ${ }^{60}$, analizując wynalezioną tradycję połajewskch spotkań kolędników-dudziarzy: niematerialne, ale czy dziedzictwo? Jednak nakładanie na praktykę społeczną kategorii analitycznych, którymi dana społeczność się nie posługuje, takich jak folkloryzm czy tradycja wynaleziona, wiąże się z ryzykiem odsunięcia na drugi plan tego, co winno być dla antropologa najważniejsze - znaczenia, które danej praktyce nadają ludzie. Moim celem nie było ustalenie zasadności czy bezzasadności wschowskiego kolędowania. Niezależnie od tego, czy tradycje kolędnicze istniały lub nie istniały na terenie ziemi wschowskiej, praktyka ta ma miejsce dzisiaj i jest zjawiskiem kulturowym powstałym w wyniku zapotrzebowania na nie lokalnej społeczności. Koalicja Wschowskich Kolędników jest swego rodzaju hybrydą folkloru, folkloryzmu i tradycji wynalezionej - wynika z wewnętrznej integracji młodego pokolenia (a nie jest instytucją mającą na celu wytworzenie tej integracji), choć czerpie etnograficzne inspiracje z innych regionów, ponieważ we własnym nie opiera się na pokoleniowo dziedziczonej tradycji kolędowania.

Podobnie jak w przypadku kolędowania połajewian, kolędnicza praktyka społeczna trafila we Wschowie i okolicznych wsiach na podatny grunt. Muzyczny potencjał stanowiła tutaj obecność szkoły muzycznej, której uczniowie i absolwenci stanowili dość dużą i zintegrowaną grupę. Przerwana ciągłość kulturowa terenu (w kontraście do bogatych tradycji innych regionów Polski) wytworzyła społeczną potrzebę wyróżniania się i praktykowania własnego zwyczaju. Mieszkańcy Wschowy, Przyczyny Górnej i Dolnej, a nawet dalszych miejscowości, takich jak Osowa Sień czy Sława, posiadając odpowiednie i wystarczające narzędzia, wprowadzili pewne novum kulturowe, które dość szybko zintegrowało się z istniejącym krajobrazem kulturowym.

W opinii Hucułów - pisze J. Cząstka-Kłapyta ${ }^{61}$ - obrzęd kolędowania ma magiczną, sprawczą moc, która daje im możliwość kontaktu z sacrum. Kolędnicy uważają kolędowanie za dar od Boga, a siebie samych za wysłanników bożych, niosących pokój, łagodność, radość, miłość i swobodę. Już w okresie przedświątecznym przygotowują się do pełnienia tej misji z niezwykłą starannością, surowo przestrzegając zasad postu i szukając wyciszenia w modlitwie. Z moich obserwacji wynika, że kolędowanie w wykonaniu Koalicji Wschowskich Kolędników nie charakteryzuje się tak głęboko religijnym

\footnotetext{
60 M. Smykowski, Niematerialne, ale czy dziedzictwo? Tradycje wynalezione w Potajewie (powiat czarnkowsko-trzcianecki) i ich popularyzacja na gruncie spoteczności lokalnej, „Еódzkie Studia Etnograficzne" 2016, t. 55, s. 218-240.

6I J. Cząstka-Kłapyta, dz. cyt., s. 170 .
} 
i duchowym znaczeniem. Nie jest uświęconą praktyką przekraczającą sferę sacrum, umożliwiającą kolędnikom osiągnięcie bożonarodzeniowej ekstazy. Niemniej jednak jest ono istotną częścią życia miasta w okresie świątecznym. Jest także pewnego rodzaju misją samych kolędników, którzy chcąc zatrzymać we Wschowie zwyczaj kolędowania, sami organizują spotkania z dziećmi i opowiadają o tym, jak to robić. Na podstawie badań przeprowadzonych na Rzeszowszczyźnie Elżbieta Dudek-Młynarska stwierdziła, że praktykowany na tym obszarze obrzęd kolędowania zmienił się pod względem znaczenia, funkcji i struktury, zanikowi uległa też „pierwotna rola zacieśniania więzi wewnątrz społeczności wiejskiej", którą realizuje się w innych przestrzeniach ${ }^{62}$. We Wschowie to właśnie kolędowanie jest jedną z takich przestrzeni, a jego znaczenie, funkcja i struktura się rozwija, nie zubaża.

Dzisiaj Święta Bożego Narodzenia kojarzą się mieszkańcom Wschowy z corocznym pochodem kolędników i wielu czeka na nich z otwartymi drzwiami. Wydarzenie to aktywizuje wschowską młodzież i młodych dorosłych, a także w pewien sposób spaja lokalną społeczność, dając jej coś, co jest dla nich „swoje” - wschowską tradycjękolędowania. Według definicji niematerialnego dziedzictwa kulturowego Narodowego Instytutu Dziedzictwa, „niematerialne dziedzictwo kulturowe nie zawsze jest oryginalne czy wyjątkowe. Każdy przejaw tego dziedzictwa jest ważny i cenny dla tych, którzy go praktykująi którym zapewnia ono poczucie przynależności do ich wspólnoty i dlatego każde zjawisko zasługuje na przetrwanie" ${ }^{6}$. Słowa te wydają się trafnym podsumowaniem działalności Koalicji Wschowskich Kolędników orazjejznaczenia dla wschowskiej społeczności, niezależnie od tego, czy kwalifikuje się ona do naukowo skonstruowanej kategorii dziedzictwa, czy też znacząco od niej odbiega.

\section{Bibliografia}

\section{Opracowania}

Bank Spótdzielczy we Wschowie 1947-2017, Warszawa 2017.

Brencz A., Wielkopolska jako region etnograficzny, Poznań 1996.

Brencz A., Wielkopolski rok obrzędowy. Tradycja i zmiana, Poznań 2006.

Brzezińska A.W., Jełowicki A., Mielewczyk W., Zatożenia, metodyka, cele. Atlas niematerialnego dziedzictwa kulturowego wsi wielkopolskiej, t. I, Szreniawa 2015.

Burszta J., Kultura ludowa - folkloryzm - kultura narodowa, „Kultura i Społeczeństwo” 1969, $\operatorname{nr}_{4}$ (13).

62 E. Dudek-Młynarska, Wspótczesne formy i funkcje kolędowania, [w:] Kolędowanie na Rzeszowszczyźnie, red. J. Dragan, K. Smyk, Kolbuszowa 2019, s. 255.

63 Definicja niematerialnego dziedzictwa kulturowego na stronie Narodowego Instytutu Dziedzictwa, http://niematerialne.nid.pl/Dziedzictwo_niematerialne/ [dostęp: I2 kwietnia 20I7]. 
Burszta J., Kultura ludowa - kultura narodowa. Szkice i rozprawy, Warszawa 1974.

Cząstka-Kłapyta J., Kolędowanie na Huculszczyźnie, Kraków 2014.

Czubala D., Opowieści żzycia. Z badań nad folklorem wspótczesnym, Katowice 1985.

Dragan W., Maksymiuk-Pacek B., Tradycyjne formy kolędowania na Rzeszowszczyźnie, [w:] Kolędowanie na Rzeszowszczyźnie, red. J. Dragan i K. Smyk, Kolbuszowa 2019.

Drożdż A, Pomoc wzajemna. Wspótdziatanie spoteczne i pomoc sąsiedzka. Komentarze do Polskiego Atlasu Etnograficznego, t. viI, red. Z. Kłodnicki, Wrocław-Cieszyn 2002.

Dudek-Młynarska E., Wspótczesne formy i funkcje kolędowania, [w:] Kolędowanie na Rzeszowszczyźnie, red. J. Dragan i K. Smyk, Kolbuszowa 2019.

Hanson A., Kreowanie Maorysa, wynalazek kultury i jego logika, przeł. J. Schmidt, [w:] Amerykańska antropologia postmodernistyczna, red. M. Buchowski, Warszawa 1999.

Hobsbawm E., Ranger T., Tradycja wynaleziona, przeł. M. Godyń, F. Godyń, Kraków 2008.

Jasiewicz Z., Linette B., Staszczak Z., Tradycja i przemiana. Studia nad dziejami i wspótczesna kultura ludowa, Poznań 1978.

Kuczyński A., Kuczyńska M.B., Kolędowanie na Lubelszczyźnie, Wrocław 1986.

Kultura Ludowa Wielkopolski, red. J. Burszta, Poznań 1967.

Kurczewska J., Szacki J., Tradycja i nowoczesność, Warszawa 1984.

Łęcki W., Stownik Krajoznawczy Wielkopolski, Warszawa-Poznań 1992.

Łęcki W., Wielkopolska. Nasza Kraina, Poznań 2004.

Maffesoli M., Czas plemion. Schytek indywidualizmu w spoteczeństwach ponowoczesnych, przeł. M. Bucholc, Warszawa 2008.

Ogrodowska B., Polskie obrzędy i zwyczaje doroczne, Warszawa 2012.

Ogrodowska B., Radość wszelkiego stworzenia. Rzecz o adwencie i Bożym Narodzeniu - historia, tradycja, obyczajpolski, Warszawa 2018.

Ogrodowska B., Swięta polskie. Tradycja i obyczaj, Warszawa 2000.

Ogrodowska B., Zwyczaje, obrzedy, tradycje w Polsce. Maty stownik, Warszawa 2000.

Przesiedlenie ludności polskiej z Kresów Wschodnich do Polski 1944-1947, red. S. Ciesielski, Warszawa 2000.

Ratajewska B., Materiaty archiwalne do dziejów Wschowy, Leszno 2013.

Stownik etnologiczny. Terminy ogólne, red. Z. Staszczak, Warszawa-Poznań 1987.

Stownik geograficzny Królestwa Polskiego i innych krajów stowiańskich, t. XIV, Warszawa 1895.

Stownik geograficzny Królestwa Polskiego i innych krajów stowiańskich, t. XV, cz. 2, Warszawa 1902.

Smykowski M., Niematerialne, ale czy dziedzictwo? Tradycje wynalezione w Potajewie (powiat czarnkowsko-trzcianecki) i ich popularyzacja na gruncie spoteczności lokalnej, "Eódzkie Studia Etnograficzne” 2016, t. 55 .

Sprungala M., Kronika Wschowy, przeł. P. Zielnica, Dortmund-Wijewo 2016.

Sprungala M., Wsie i miasta na pograniczu gtogowsko-wielkopolskim. Zarys dziejów wybranych miejscowości, przeł. P. Zielnica, Dortmund-Wijewo 2018.

Sulima R., Folklor i literatura. Szkice o kulturze i literaturze wspótczesnej, Warszawa 1985.

Szacki J., Tradycja. Przeglad problematyki, Warszawa 1971.

Zadrożyńska A., Powtarzać czas początku, Warszawa 1985.

Zadrożyńska A., Światy, zaświaty. O tradycji świętowań w Polsce, Warszawa 2000.

Zadrożyńska A., Świętowania polskie. Przewodnik po tradycji, Warszawa 2002.

Ziemia Lubuska, red. M. Sczaniecki, S. Zajchowska, Poznań 1950.

Streszczenie: Celem artykułu jest analiza działalności Koalicji Wschowskich Kolędników - grupy młodych ludzi z okolic Wschowy (woj. lubuskie), która w okresie Świąt Bożego Narodzenia praktykuje obchody kolędnicze ulicami miasta i przylegających do niego wsi. Jest to zjawisko stosunkowo świeże, które z uwagi na brak przekazu międzypokoleniowego 
w formie i treści czerpie z różnych regionów Polski. Artykuł składa się z trzech części: I) etnograficznego opisu kolędowania, prezentacji grupy i społecznego odbioru zjawiska, 2) osadzenia wschowskiego kolędowania na tle wielkopolsko-lubuskich tradycji kolędniczych, 3) analizy przypadku w kategoriach tradycji, folkloryzmu, tradycji wynalezionej i niematerialnego dziedzictwa kulturowego.

Słowa klucze: niematerialne dziedzictwo kulturowe, folkloryzm, tradycja wynaleziona, kolędowanie

Summary: The aim of the article is to analyze the activities of the carol formation named „Koalicja Wschowskich Kolędników” - a group of young people from Wschowa in western Poland, who practice Christmas carol singing celebrations around the streets of the city and near villages. This recent phenomenon due to the lack of intergenerational communication draws from various regions of Poland. The article consists of three parts: I) ethnographic description of the group, its activity and social perception, 2) locating it in the background of regional carol traditions, 3 ) case study in terms of tradition, folklore, invented tradition and intangible cultural heritage.

Keywords: intangible cultural heritage, folklore, invented tradition, carols singing 